\title{
ATEBE
}

Dinî Araștırmalar Dergisi

Journal for Religious Studies

ATEBE Dergisi / Journal of ATEBE

e-ISSN: 2757-5616| Haziran / June 2021/1, 5: 153-156

\section{Din Eğitiminin Sosyal Medya Kullanımına Etkisi. Süleyman Gümrükçüoğlu. Ankara: Nobel Bilimsel Eserler Yayınları, 2020, 145 sayfa}

\section{Değerlendiren/Reviewed by Merve Aydemir}

Yüksek Lisans Öğrencisi, Sakarya Üniversitesi, Sosyal Bilimler Enstitüsü, Felsefe ve Din Bilimleri Anabilim Dalı

M.A. Student, Sakarya University, Institute of Social Sciences, Department of Philosophy and Religious Sciences

Sakarya, Turkey

merve.aydemir1995@gmail.com

orcid.org/ 0000-0002-3866-3630

\section{Makale Bilgisi / Article Information}

Makale Türü/Article Types: Kitap Değerlendirmesi / Book Review

Geliş Tarihi / Date Received: 21 Nisan/April 2021

Kabul Tarihi /Date Accepted: 10 Mayıs/May 2021

Yayın Tarihi / Date Published: 15 Haziran/June 2021

Yayın Sezonu / Pub Date Season: Haziran/June

Atıf / Cite as: Aydemir, Merve. Din Eğitiminin Sosyal Medya Kullanımına Etkisi. Süleyman Gümrükçüoğlu. Ankara: Nobel Bilimsel Eserler Yayınları, 2020, 145 sayfa." ATEBE 5 (Haziran 2021), 153-156. https://doi.org/10.51575/atebe.923867

İntihal / Plagiarism: Bu makale, iTenticate yazılımınca taranmıștır. İntihal tespit edilmemiștir/This article has been scanned by iTenticate. No plagiarism detected.

Etik Beyan/Ethical Statement: Bu çalışmanın hazırlanma sürecinde bilimsel ve etik ilkelere uyulduğu ve yararlanılan tüm çalışmaların kaynakçada belirtildiği beyan olunur/It is declared that scientific and ethical principles have been followed while carrying out and writing this study and that all the sources used have been properly cited (Merve Aydemir).

Copyright (C) Published by Ankara Sosyal Bilimler Üniversitesi, İslami İlimler Fakültesi / Social Sciences University of Ankara, Faculty of Islamic Sciences, Ankara, 06050 Turkey. All rights reserved.

CC BY-NC-ND 4.0 | This paper is licensed under a Creative Commons Attribution-NonCommercial NoDerivatives International License. 


\title{
Din Eğitiminin Sosyal Medya Kullanımına Etkisi. Süleyman Gümrükçüoğlu. Ankara: Nobel Bilimsel Eserler Yayınları, 2020, 145 s.
}

$\ddot{0} \mathbf{z}$

Teknoloji, bireyleri ve toplumları etkileyen önemli bir unsurdur. Buna bağlı olarak gelişen sosyal medyanın bugün hayatımızda kapsadığı alan yadsınamaz bir gerçeklik teșkil etmektedir. Bu alan her yeni kuşakla birlikte daha da büyüyerek etkilerini göstermektedir. Bu dijital ortam; öğrenmelerin, taklit etmelerin, rol model almaların ve hedeflerin kaynağı hâline gelmiștir. Sosyal medyanın yoğun kullanımı her alanda olduğu gibi bireylerdeki inanç, tutum ve dini değerlerin şekillenmesinde de önemli bir rol oynamaktadır. Bu bağlamda, özellikle son dönemde din ile sosyal medya konularına odaklanan çalıșmaların arttığı görülmektedir. Bu nedenle, sosyal medya kullanımının, dini düşünce ve ahlaki tutumlardaki dönüşümünü problem edinen ve bunun giderilmesinde din eğitiminin önemini ele alan Süleyman Gümrükçüoğlu'nun Din Eğitiminin Sosyal Medya Kullanımına Etkisi adlı eseri incelenmiştir.

Anahtar Kelimeler: Din Eğitimi, Sosyal Medya, Din, İnternet, Teknoloji

\section{The Effect of Religious Education on Social Media. Süleyman Gümrükçüoğlu. Ankara: Nobel Scientific Publications, 2020, 145 s.}

\begin{abstract}
Technology is an important element that affects individuals and societies. Accordingly, the fact that social media plays an important role in our daily lives is undeniable today. This area is growing with each new generation and showing its effects. This digital environment has become the source of learning, imitation, role modelling and goals. The intensive use of social media plays a significant role in shaping beliefs, attitudes and religious values in individuals as well as in all areas. In this context, it is seen that studies focusing on religion and social media have increased recently. This article, therefore, reviews Süleyman Gümrükçüoğlu's book, the Effect of Religious Education on the Use of Social Media, in which he takes the transformation of the use of social media in religious thinking and moral attitudes as a problem and addresses the importance of religious education in the elimination of this problem.
\end{abstract}

Keywords: Religious Education, Social Media, Religion, Internet, Technology

İnternet, hayatımızda bu kadar merkezi bir konuma yerleşmişken din ve medyanın birbirinden etkilenmemiş olması düşünülemez. Çağın gereği olarak pek çok yeniliği hayatımıza getiren dijital medya bireylerin dinsel yaşam, dini algılayıș ve dini araştırma biçimlerini de buna paralel olarak değiştirmiştir. Bu bağlamda hayatımızın her alanına nüfuz eden internet, beraberinde "sosyal medya ve din" ilişkisini gündeme getirmiştir.1

İşte bu alana katkı sağlaması amacıyla kaleme alınan elimizdeki eser, Kocaeli Üniversitesi İlahiyat Fakültesi Felsefe ve Din Bilimleri Ana Bilim Dalı Dr. Öğr. Üyesi Süleyman Gümrükçüoğlu tarafından kaleme alınmış ve 2020 yılında yayımlanmıştır. Eserde sosyal medya kullanımından yola çıkılarak ilgili kavram ve konular açılanmış ve bu alanın bireylerde dini-ahlaki ilkeler bağlamında nasıl bir tahribata yol açtığı incelenmiştir. Giderek hayatımızın merkezine yerleşen sosyal medyanın tarihi süreç içerisinde nasıl bir gelişme gösterdiği ele alınarak, her yaş grubuna ait bireyleri ilgilendiren bu alanın değer yargılarımıza yansımasından yola çıkılmış ve kullanıcılarının nasıl bir tutum sergilemesi gerektiği tespit edilerek önerilerle ortaya konmak istenmiştir. Eserde verilerin tespitinde son güncel araştırma istatistiklerine yer verilmiş, din eğitimi merkezde olmak üzere birçok araştırmadan faydalanılmış ayrıca konular yer yer ayet ve hadislerle desteklenmiştir.

Elimizdeki bu eserin giriş ve sonuç kısmı dışında: "Din Eğitimi ve Fonksiyonları", "İnternet ve Sosyal Medya" ve "Ahlaki İlkeler ve Sosyal Medya" isimli üç ana bölümden

1 Ahmet Eskicumalı-Yıldız Kol, “Dijital Medya ve Din”, Sakarya Üniversitesi İletişim Çalışmaları 2019, (31 Aralık 2019), 12-13. 
oluştuğunu görmekteyiz. Kitabın giriş bölümünde, ele alınan probleme değinilmesi ve üç ana başlıkta hangi konuların yer aldığının kısaca belirtilmesi, okuyucuya kitabın içeriği hakkında bir ön bilgi oluşturması açısından önemlidir (s. 2-3). Birinci bölüm olan 'Din Eğitimi ve Fonksiyonları' başlığı kapsamında din eğitiminin tanımı yapılmış ardından bireysel ve sosyal fonksiyonları üzerinde durulmuştur. Burada sık sık eğitim kavramı vurgulanarak, eğitim ve öğretim kavramlarının sözlük anlamları üzerinden tahlilleri yapılmıştır (s. 8). Yazar, din ve eğitimin amaçlarını ele aldıktan sonra iki kavramın ortak amacını 'bireyin inanma ve bağlanma ihtiyaçlarının planlı ve programlı bir șekilde sağlanması' olarak tanımlamıș ve İslam'ın din eğitimi için belirlediği hedefler ve temel prensipleri maddeler hâlinde açıklamıştır (s. 9). Bu bölümde dini inanç ile ahlak kavramını bağdaştıran yazar, "dini inanç olmazsa ahlakın yaptırım gücünün zayıflayacağını" ve "toplumsal değişim ve dönüşümün ancak dinin bireylerde oluşturduğu etkiyle mümkün olabileceğini" vurgulamıştır (s. 24-26).

"İnternet ve Sosyal Medya" başlıklı ikinci bölüm kitabın odak noktasını oluşturmaktadır. $\mathrm{Bu}$ bölümde internet ve sosyal medyanın gelişim süreci tarihsel bağlamda ayrıntılı olarak ele alınmıştır. Yazar, günümüzde kullanılan sosyal medya mecralarının çıkış öncülerine de yer vermiş ve ilk bölümde olduğu gibi burada da meseleye kavramsal açıklamalarla giriş yaparak başlamıştır. Sosyal medya platformlarının genel özelliklerini sıralayan yazarın, sosyal medya açısından önemli bir kavram olan paylaşım kavramını ayrı bir kavram olarak ele almadığı, bu kavramın toplum kavramı içerisinde geçtiği görülmektedir. Burada toplum ve bağlantılılık kavramları arasında paylaşım kavramına da yer verilmesinin hem bu iki kavram arasındaki bağlantının hem de kavramsal akışın sağlanması açısından ele alınabileceği düşüncesindeyiz. Eserde sosyal paylașım ağlarının kesin bir șekilde kategori edilemeyeceği belirtildikten sonra yazarın genel çerçeve kapsamında sosyal ağlar ve fotoğraf paylaşım siteleri şeklinde kategori oluşturarak meseleye değinmesi ise oldukça önemlidir. İkinci başlık olan fotoğraf paylaşım siteleri kısmında Instagram kavramının çok sınırlı ele alındığı görülmektedir. Hem dünyada hem de ülkemizde sosyal medya kullanım oranlarını ele alan yazarın güncel istatistik verilerini kullanarak aktarması meselenin ehemmiyetini görmek açısından önemli bir noktayı oluşturmaktadır. Belki de en önemli kısım olan sosyal medyanın olumlu ve olumsuz etkilerini başlıklar altında değerlendiren yazarın, olumsuz etkileri kısmında bu etkileri maddeler hâlinde tek tek ele alma gayretinde olduğu görülürken olumlu etkileri kısmında ise güncel bir kitap olması hasebiyle özellikle bu dönemde sürekli gündemimizde olan uzaktan eğitim sistemi, telekonferans görüşmeleri, internet bankacılığı ve online sipariş sistemleri gibi hayatımıza yerleşen unsurlara yer vermemesi dikkat çekmektedir.

Üçüncü ve son bölüm olan "Ahlaki İlkeler ve Sosyal Medya" kısmında ise eserin başlığı olan din eğitiminin etki kısmı ahlak kavramı merkeze alınarak ayrıntılı bir șekilde ele alınmıștır. $\mathrm{Bu}$ kısımda sık sık hadis ve ayetlere yer verilmesi konunun pekiştirilmesi ve dayanak olușturması bakımından oldukça önemlidir. Birey tarafından içselleștirilen inanç ve değerleri etkileme ve değiștirme gücüne sahip olan medyanın bu yönü, yazara göre realiteden kopuk olmasıyla ilişkilendirilmiştir. Yazarın sanal ortamın ilgi çekici ve cazip yönlerine vurgu yapması ve kişiyi başka bir kllığa bürüdügünü belirtmesi ise akıllara Jean Baudrillard'ın: "modeller ve imgelerin gerçekliğin yerini almalarının hakiki ve sahte olan arasındaki sınırları ortadan kaldırmaya yönelik bir strateji olduğu"2 sözünü getirmektedir. Eserde "klavye delikanlılığı, dikizleme kültürü ve stalk" gibi sanal ortamlarda ortaya çıkan yeni kavramlara da yer verilmiştir. Eserde, yapmadığı hâlde sosyal medyada o ibadeti yapıyor(muş) gibi görünen bireylerin oranlarının verildiği kısım ise oldukça dikkat çekicidir. Bu bölümde sosyal medya platformlarının bireylerin inançsal normları ve ahlaki ilkelerinde ne denli bir tahribata yol açtığını ayrıntılı bir şekilde inceleyen yazar; bu doğrultuda günümüzde oldukça önem arz eden dini medya okuryazarlığına da değinmiştir. Yazar, medyayı tüketen kişilerde, eleştirel ve analitik düşünme yetisini kazandırması bakımından bu kavrama oldukça önem atfetmiştir. Eserde kișiliği zedeleyici ihlaller tek tek ele alınarak ayrıntılı incelemeler yapılmıș ve tecessüs kavramı üzerinde durulmuştur. Yazar tarafından sosyal mecralarda gerçekleşen ortam dinlemeleri, kayıtlar ve izlemeler bu kavramla bağdaştırılmış olup İslamiyet'in özüne muhalif bir tutum olduğu vurgulanmıştır. Eserde üzerinde durulan bir diğer kavramın ise mahremiyet kavramı

\footnotetext{
2 Jean Baudrıllard, Karnaval ve Yamyam (İstanbul: Boğaziçi Üniversitesi Yayınevi, 2012), 60.
} 
olduğu görülmektedir. Yazar burada kavramı hem tarihsel süreci hem de tüm ilişik kavramlarıyla birlikte ele alarak genel anlamda takip etme, ifşa ve özel hayatın gizliliği üzerinden açıklamalarda bulunmuştur. Ayrıca bu kısımda mimari ile mesken mahremiyeti ilişkilendirilerek okuyucuya konu farklı bir perspektiften sunulmuştur.

Sonuç ve öneriler kısmında ise yazar; ölçülü, dikkatli ve bilinçli sosyal medya kullanımına dikkat çekmiş bireyin din ve değerler eğitimi gibi alanlarla desteklenmesinin haiz-i ehemmiyetini belirtmiştir. $\mathrm{Bu}$ kısımda bulgular doğrultusunda yol gösterici önerilerin belirtilmesi ise problem olarak ele alınan konu açısından oldukça kıymetlidir.

İncelemeye aldığımız eseri biçimsel açıdan değerlendirecek olursak kapak kısmında yer alan görsellerin ilgi çekici olduğunu söyleyebiliriz. Eserin sonraki baskılarında ön söze de yer verilebilir. Kitapta eser miktarda bulunan imla hatalarının gözden kaçmış olmasının eserin ilk baskısı olmasından kaynaklı olabileceği kanaatindeyiz.

Son olarak kitabın arka kapağında eserin yalnızca akademisyen, öğretmen ve din görevlileri için değil sosyal hayatta yer alan tüm bireyler için fayda sağlayıcı olduğu belirtilmiştir. Kitap okunabilirlik ve içerik açısından her kesime hitap edebilir niteliktedir. Ancak eserde, sosyal medya uygulamalarının kullanım şekillerine ve etki yönlerine en güncel hâliyle daha fazla yer verilmesinin dikkat çekiciliği ve farkındalığı artırabileceği düşüncesindeyiz. Mesela Instagram ve Youtube uygulamalarının yer aldığı bölümlerde hayatımıza yerleșen ve gençler için idolleşen "influencer, youtuber" gibi kavramlar ele alınabilir, bu platformların tüketim alışkanlığı kazandırma amaçları ile israf kavramı arasında ilişki kurulabilir. İncelemiş olduğumuz eseri bașlık-içerik uyumu açısından değerlendirdiğimizde ise bașlıkta yer alan "din eğitiminin etkisi" kısmından ziyade eserin içeriğinde sosyal mecralardaki tutum, davranış ve olguların İslam'a uygunluğunun temellendirilmesinin daha fazla yer aldığını söyleyebiliriz. Bahsedilen bu hususlar eserin kapsamının ve ilgi çekiciliğinin artması yönünden tavsiye niteliğinde belirtilmiştir.

Gelişen dünya ile beraber hayatımızın merkezine yerleştirdiğimiz teknoloji, giderek daha da önem arz eden bir hâle gelmiş ve üzerinde ciddi çalışmalar yapılması gerekliliğini ortaya çıkarmıştır. Bu bağlamda kaleme alındığı düşünülerek incelemeye aldığımız eser, teknoloji ile birlikte hayatımızın merkezine yerleştirdiğimiz sanal platformların bireylerin alışkanlıklarında, inançsal olgularında ve ahlaki ilkelerinde ne denli bir değişim ve dönüşüm oluşturduğunun gözler önüne serilmesi açısından oldukça önemli ve dikkat çekicidir.

Elimizdeki çalışma araştırılması ve incelenmesi giderek daha da önem arz eden bu sahaya önemli bir katkıda bulunmuştur. Eser bu alanda çalışma yapmayı düşünen araștırmacılar için başvurulabilecek bir kaynak olup aynı zamanda içeriğindeki karşılaştırmalar ve örneklemelerle fayda sağlayıcı, özellikle öneriler kısmında belirtilen hususlarla da hem ilgili alana hem de tüm bireylere yol gösterici nitelikli olduğu söylenebilir.

\section{Kaynakça}

Baudrıllard, Jean. Karnaval ve Yamyam. İstanbul: Boğaziçi Üniversitesi Yayınevi, 2012.

\section{Eskicumall, Ahmet - Kol, Yıldız. “Dijital Medya ve Din”. Sakarya Üniversitesi İletişim Çalışmaları} $2019,12-20$. 